\title{
Working conditions, lifestyle and mental health of Brazilian public-school teachers during the COVID-19 pandemic
}

\author{
Nayra Suze Souza e Silva, ${ }^{1}$ Rose Elizabeth Cabral Barbosa, ${ }^{1}$ Luana Lemos Leão, ${ }^{1}$ \\ Geórgia das Graças Pena, ${ }^{2}$ Lucineia de Pinho, ${ }^{3}$ Tatiana Almeida de Magalhães, ${ }^{1}$ \\ Marise Fagundes Silveira, ${ }^{1}$ Luiza Augusta Rosa Rossi-Barbosa, ${ }^{3}$ \\ Rosângela Ramos Veloso Silva, ${ }^{3}$ Desirée Sant'Ana Haikal ${ }^{1}$ \\ 'Health Sciences Department, State University of Montes Claros - Unimontes, Minas Gerais, \\ ${ }^{2}$ Health Sciences Department, Federal University of Uberlândia, Uberlândia, Minas Gerais, \\ ${ }^{3}$ Graduate Program in Primary Health Care, State University of Montes Claros - Unimontes, Minas Gerais, Brazil
}

ARTICLE HISTORY: Received 28 April 2021/Revised 21 July 2021/Published Online 26 November 2021

\begin{abstract}
This study aimed to describe the working conditions, lifestyle and mental health of Brazilian public-school teachers during the COVID-19 pandemic. This is an epidemiological websurvey, carried out from August to September 2020. Teachers from public schools in rural and urban areas in the state of Minas Gerais, Brazil, participated in the study. A digital questionnaire was used and the study addressed variables related to four major thematic topics: sociodemographic and economic profile, working conditions, lifestyle and health conditions, and mental health problems during the pandemic. The sample consisted of 15,641 teachers, of which $13.3 \%$ worked in rural areas, $81.9 \%$ were women, $56.2 \%$ were aged $41-60$ years, $66.8 \%$ were married, $99.2 \%$ were working remotely and $79.8 \%$ adhered to social distancing. During the pandemic, $40.6 \%$ showed a decrease in family income, $33.7 \%$ were dissatisfied with their work, 58\% reported increased body weight, $47.9 \%$ did not exercise, 35.8\% were part of at least one risk group for COVID-19, 40.5\% had some flu-like symptoms during the pandemic and $1.2 \%$ tested positive for COVID-19. Regarding mental health problems, $25.9 \%$ of teachers self-reported formal diagnosis of anxiety and/or depression during the pandemic. In addition, $7.1 \%$ of teachers were drinking more alcohol than usual, $33.4 \%$ started having sleep problems, 30.4\% were using relax/sleep/anxiety/depression medications, $67.1 \%$ reported that their quality of life worsened and $43.7 \%$ reported having severe fear of COVID-19. It was also found that $82.3 \%$ of teachers had at least one mental health problem during the pandemic, such as increased alcohol consumption, sleep problems, use of psychotropic medication, decreased quality of life, and fear of COVID-19. The results of this study reveal the numerous challenges and the extent of the impact of the pandemic on working conditions, lifestyle, and especially on the mental health of teachers.
\end{abstract}

KEYWORDS: Coronavirus, education, health conditions, work stress, epidemiology.

\section{Introduction}

In 2019, the SARS-CoV-2 pandemic started and quickly spread around the world. In January 2020, COVID-19 was announced by World Health Organization WHO as a public health emergency. ${ }^{1}$ The first case of COVID-19 was confirmed in Brazil in February 2020 and after three weeks, all Brazilian states presented at least one case of the disease. ${ }^{2}$

As a result of the increase in the number of deaths, the most widely adopted public health measure was social

Corresponding author: Nayra Suze Souza e Silva, Av. Rui Braga, S/No - Vila Mauricéia CEP 39401-089, Montes Claros, Minas Gerais, Brazil • e-mail: nayrasusy@hotmail.com 
distance. ${ }^{3}$ Social distancing was applied to reduce contact between people. Many measures were adopted during the pandemic, such as border closures, non-essential commercial establishments have been closed, and the prohibition of public events. ${ }^{4}$ COVID-19 caused damage even to the educational system. ${ }^{5}$ Teachers faced financial, physical, and mental problems, due to changes in the routine of life and work. ${ }^{6}$

As a result of the pandemic extension in Brazil, in April 2020, the National Council of Education approved an emergency strategy on the reorganization of the school calendar and the possibility of remote classes, aiming at fulfilling the country's annual workload. ${ }^{7}$ This "new normal" generated consequences and concerns for teachers, directly affecting working conditions, life habits, and health, ${ }^{8}$ especially those of public basic education, who work in schools with precarious structures, with high working hours, and sometimes in more than one educational institution. ${ }^{9}$

Although the pandemic is recent, the literature already presents studies on the impact caused on the population's health and work. ${ }^{10-13}$ However, the extent of the changes caused in the health and working conditions of basic education teachers is still unclear. Therefore, this study aimed to describe the working conditions, lifestyle, and mental health of Brazilian teachers during the COVID-19 pandemic.

\section{Material and Method}

This study is part of the ProfSMoc Project - Minas Covid Stage "Health and work conditions among teachers from the state education system of Minas Gerais during the COVID-19 pandemic". This is a cross-sectional study, carried out with teachers of elementary, middle, and high school from public schools in the state of Minas Gerais, Brazil. The state of Minas Gerais had approximately 90,000 teachers of basic education in 2020 working in 3,441 schools. ${ }^{14}$ This study followed the Checklist for Reporting Results of Internet E-Surveys. ${ }^{15}$

The sample calculation was made considering infinite populations. A prevalence of $50 \%$ was considered aiming to obtain the largest sample size and inference power. The tolerable error adopted was 3\%. The sample was duplicated deff $=2$, as it is a conglomerate. A $20 \%$ increase was made in the sample size to compensate for possible losses. Thus, a minimum sample of 2,564 teachers was estimated.

Organizationally, the state of Minas Gerais is divided into six regional centers and each center is subdivided into Regional Teaching Superintendencies (RTS). Altogether, the state has 45 RTS. Access to the number of teachers and to which RTS the teacher was linked was made available by the Department of Education of Minas Gerais (DE$M G)$. Thus, it was possible to guarantee the proportionality of teachers by RTS, stipulating the minimum number of teachers to be studied in each of the RTS.

Authorizations were obtained from the DE-MG and 45 RTS to carry out the research. A pilot study was carried out with 20 teachers from five different cities in Minas Gerais to test and adjust the data collection. Data collection took place from August 20 to September 11, 2020, using a digital form. The link to the digital form was sent to the institutional e-mail of all teachers in the state, which had the support of DE-MG in sending them. To avoid automatic filling of the form by computer systems, a reCAPTCHA was used, preventing the form from being sent by robots. All questions on the form were mandatory, minimizing information loss. The study also guaranteed the teachers' anonymity.

This study included teachers working in elementary, middle, and/or high school, and those who accepted to participate in the research. Teachers deviating from the teaching function and those who answered "no" when asked if they agreed to participate in the study were excluded.

The study addressed four major thematic groups of variables: sociodemographic and economic profile, working conditions, lifestyle and health conditions, mental health problems, including the Fear of COVID-19 Scale (FCV-19S), which is an instrument that investigates people's fear of COVID-19. The total score was obtained from the sum of the items, being categorized from 7 to 19 points as "little fear", from 20 to 26 points "moderate fear" and 27 to 35 points "severe fear."16

The data were analyzed using the Statistical Package for Social Sciences, version 22.0. Simple frequencies were presented, the prevalence and $95 \%$ confidence interval $95 \% \mathrm{Cl}$ were calculated for the variables studied.

The project was approved by a research ethics committee of the State University of Montes Claros (4,200,389/2020). The research also complied with resolution $466 / 12$ of the National Health Council/Ministry of Health.

\section{Results}

The questionnaire was accessed by 16,210 teachers, of which 15,641 agreed to participate in the survey, resulting in a recruitment rate of $96.5 \%$ and a $100 \%$ completion rate. Most of the teachers (86.7\%) worked in the urban area, while $13.3 \%$ worked in schools located in rural areas. The sociodemographic and economic profiles of the sample are shown in table 1. The majority of the teachers were female $(81.9 \%), 56.2 \%$ were aged 41 to 60 years, $59.5 \%$ 
Table 1. Sociodemographic and economic profile of public-school teachers $(n=15,641)$.

\begin{tabular}{|c|c|c|}
\hline & $\mathrm{n}$ & $\%(\mathrm{Cl} 95 \%)$ \\
\hline \multicolumn{3}{|l|}{ Gender } \\
\hline Female & 12,817 & $81.9(81.2-82.5)$ \\
\hline Male & 2,824 & $18.1(17.4-18.7)$ \\
\hline \multicolumn{3}{|l|}{ Age years } \\
\hline $21-40$ & 6,447 & $41.2(40.4-41.9)$ \\
\hline $41-60$ & 8,793 & $56.2(55.4-56.9)$ \\
\hline$>60$ & 401 & $2.6(2.3-2.8)$ \\
\hline \multicolumn{3}{|l|}{ Skin color/ethnicity } \\
\hline White & 7,642 & $48.9(48.1-49.6)$ \\
\hline Brown & 6,321 & $40.4(39.6-41.1)$ \\
\hline Black & 1,246 & $8.0(7.5-8.4)$ \\
\hline Asian & 359 & $2.3(2.0-2.5)$ \\
\hline Indigenous & 73 & $0.5(0.3-0.6)$ \\
\hline \multicolumn{3}{|l|}{ Living area } \\
\hline Urban area & 13,565 & $86.7(86.1-87.2)$ \\
\hline Rural area & 2,076 & $13.3(12.7-13.8)$ \\
\hline \multicolumn{3}{|l|}{$\begin{array}{l}\text { Family income before } \\
\text { the pandemic } \\
\text { (minimum wage) \# }\end{array}$} \\
\hline $1-2$ & 3,969 & $25.4(24.7-26.0)$ \\
\hline $3-5$ & 9,301 & $59.5(58.7-60.2)$ \\
\hline $6-9$ & 1,945 & $12.4(11.8-12.9)$ \\
\hline$>10$ & 426 & $2.7(2.4-2.9)$ \\
\hline \multicolumn{3}{|l|}{$\begin{array}{l}\text { Family income during } \\
\text { the pandemic }\end{array}$} \\
\hline Increased & 304 & $1.9(1.6-2.1)$ \\
\hline Remained the same & 8,947 & $57.2(56.4-57.9)$ \\
\hline Decreased & 6,350 & $40.6(39.8-41.3)$ \\
\hline Lost the income & 40 & $0.3(0.2-0.3)$ \\
\hline \multicolumn{3}{|l|}{ Marital status } \\
\hline Married & 10,453 & $66.8(66.0-67.5)$ \\
\hline Not married & 5,188 & $33.2(32.4-33.9)$ \\
\hline \multicolumn{3}{|l|}{ Children } \\
\hline Yes & 11,350 & $72.6(71.9-73.2)$ \\
\hline No & 4,291 & $27.4(26.7-28.0)$ \\
\hline
\end{tabular}

*Variation in $\mathrm{n}$ due to loss of information

\#Quantity of minimum wages received by the family. Brazilian national minimum wage $=\$ 212.6 /$ month.

had family incomes of 3 to 5 minimum wages, $40.6 \%$ had a decrease in family income during the pandemic, $66.8 \%$ were married and $72.6 \%$ had children.

Table 2 shows data on working conditions. A quarter of the teachers worked as teachers for 21 years or more, $15.8 \%$ worked more than 40 hours per week, $4.4 \%$ had a MSc and/ or $\mathrm{PhD}$ degree, $99.2 \%$ were doing remote work and $33.7 \%$ were dissatisfied with work during the pandemic.
Table 2. Working conditions of public-school teachers $(n=15,641)$

\begin{tabular}{lrc}
\hline \multicolumn{1}{l}{$\mathrm{n}$} & $\%(\mathrm{Cl} 95 \%)$ \\
\hline Years of teaching work * & & \\
$1-10$ & 5,941 & $38.0(37.2-38.7)$ \\
$11-20$ & 5,788 & $37.0(36.2-37.7)$ \\
$>21$ & 3,911 & $25.0(24.3-25.6)$ \\
Weekly hours of teaching work * & & \\
$\leq 19$ & 3,613 & $23.1(22.4-23.7)$ \\
$20-39$ & 9,554 & $61.1(60.3-61.8)$ \\
$\geq 40$ & 2,472 & $15.8(15.2-16.3)$ \\
Graduate degree & & \\
Master's and/or PhD & 692 & $4.4(4.0-4.7)$ \\
Specialization & 11,115 & $71.1(70.3-71.8)$ \\
No & 3,834 & $24.5(23.8-25.1)$ \\
Performing remote work & & \\
during the pandemic & & \\
Yes & 15,520 & $99.2(99.0-99.3)$ \\
No & 121 & $0.8(0.6-0.9)$ \\
Work satisfaction during & & \\
the pandemic & & \\
Satisfied & & \\
Neither satisfied nor dissatisfied & 6,995 & $44.7(43.9-45.4)$ \\
Dissatisfied & 5,271 & $33.7(32.9-34.4)$ \\
\hline * Variation in $n$ due to loss of information & \\
\hline & &
\end{tabular}

Regarding the lifestyle and health conditions, $79.8 \%$ fully adhered to social distancing, $47.9 \%$ were not exercising, 53\% were not performing leisure activities, 58\% had gained weight, $35.8 \%$ were part of at least one risk group for COVID-19, 40.5\% had some flu-like symptoms during the pandemic and $1.2 \%$ tested positive for COVID-19. These and other data are included in table 3.

Table 4 presents topics related to mental health. It was observed that $25.9 \%$ of teachers reported a formal diagnosis of anxiety and/or depression during the COVID-19 pandemic. Before the pandemic, 32.3\% of teachers reported that they had been previously diagnosed by a doctor with anxiety and/or depression. Furthermore, during the pandemic, $7.1 \%$ of the teachers were drinking more alcohol than usual, 33.4\% started having sleep problems, $30.4 \%$ were using drugs to relax/sleep/anxiety/depression, the perception of quality of life of $67.1 \%$ of teachers worsened and $43.7 \%$ reported having severe fear of COVID-19. It was also found that $82.3 \%$ of teachers had at least one condition related to mental health during the pandemic, such as increased alcohol consumption, sleep problems, use of psychotropic medication, quality of life, and fear of COVID-19. Those who reported a formal diagnosis of depression and/or anxiety during the pandemic were not included in the analysis. 
Table 3. Lifestyle and health conditions of public-school teachers during the pandemic $(n=15,641)$.

\begin{tabular}{|c|c|c|}
\hline & $\mathrm{n}$ & $\%(\mathrm{Cl} 95 \%)$ \\
\hline \multicolumn{3}{|l|}{ Adherence to social distance } \\
\hline Totally & 12,486 & $79.8(79.1-80.4$ \\
\hline Partially & 3,096 & $19.8(19.1-20.4$ \\
\hline Did not adhere & 59 & $0.4(0.3-0.5)$ \\
\hline \multicolumn{3}{|l|}{ Food Consumption } \\
\hline $\begin{array}{l}\text { More vegetables and fruits } \\
\text { less processed food }\end{array}$ & 7,737 & $49.5(48.7-50.2$ \\
\hline $\begin{array}{l}\text { Less vegetables and fruits; } \\
\text { more processed food }\end{array}$ & 7,904 & $50.5(49.7-51.2$ \\
\hline \multicolumn{3}{|l|}{ Practice exercise } \\
\hline Yes & 8,144 & $52.1(51.3-52.8$ \\
\hline No & 7,497 & $47.9(47.1-48.6$ \\
\hline \multicolumn{3}{|l|}{ Leisure Activities } \\
\hline Increased & 876 & $5.6(5.2-5.9)$ \\
\hline Did not change & 3,005 & $19.2(18.5-19.8$ \\
\hline Decreased & 5,033 & $32.2(31.4-32.9$ \\
\hline Not doing leisure activities & 6,727 & $43.0(42.2-43.7$ \\
\hline \multicolumn{3}{|l|}{ Body weight * \# } \\
\hline Remained the same & 4851 & $31.5(30.7-32.2$ \\
\hline Decreased & 1611 & $10.5(10.0-10.9$ \\
\hline Increased & 8933 & $58.0(57.2-58.7$ \\
\hline \multicolumn{3}{|l|}{ Risk group for COVID-19 } \\
\hline No & 10,047 & $64.2(63.4-64.9$ \\
\hline Yes & 5,594 & $35.8(35.0-36.5$ \\
\hline \multicolumn{3}{|l|}{ Flu-like symptoms } \\
\hline No & 9,312 & $59.5(58.7-60.2$ \\
\hline Yes & 6,329 & $40.5(39.7-41.2$ \\
\hline \multicolumn{3}{|l|}{ Tested positive for COVID-19 } \\
\hline Did not test & 13,627 & $87.1(86.5-87.6$ \\
\hline No & 1,788 & $11.4(10.9-11.8$ \\
\hline Did not receive the result & 41 & $0.3(0.2-0.4)$ \\
\hline Yes & 185 & $1.2(1.0-1.3)$ \\
\hline \multicolumn{3}{|c|}{$\begin{array}{l}\text { A friend or family member } \\
\text { has died because of COVID-19 }\end{array}$} \\
\hline No & 12,442 & $79.5(78.8-80.1$ \\
\hline Yes & 3,199 & $20.5(19.8-21.1$ \\
\hline
\end{tabular}

* Variation in $\mathrm{n}$ due to loss of information

\# Pregnant women were excluded from the analysis $n=232$

\section{Discussion}

This study aimed to describe the working conditions, lifestyle, and mental health of Brazilian public-school teachers during the COVID-19 pandemic. The results show that, during the pandemic, teachers suffered from financial difficulties and changes in many aspects, including their mental health.
Table 4. Mental health problems of public-school teachers during the pandemic $(n=15,641)$.

\begin{tabular}{|c|c|c|}
\hline & $\mathrm{n}$ & $\%(\mathrm{Cl} 95 \%)$ \\
\hline \multicolumn{3}{|l|}{$\begin{array}{l}\text { A medical diagnosis of anxiety and/ } \\
\text { or depression during the pandemic }\end{array}$} \\
\hline No & 11,597 & $74.1(73.4-74.7)$ \\
\hline Yes & 4,044 & $25.9(25.2-26.5)$ \\
\hline \multicolumn{3}{|l|}{$\begin{array}{l}\text { Formal diagnosis of anxiety and/or } \\
\text { depression before the pandemic }\end{array}$} \\
\hline No & 10,594 & $67.7(66.7-68.4)$ \\
\hline Yes & 5,047 & $32.3(31.5-33.0)$ \\
\hline \multicolumn{3}{|l|}{ Alcohol consumption } \\
\hline $\begin{array}{l}\text { Did not consume before and not } \\
\text { consuming during the pandemic }\end{array}$ & 8,052 & $51.5(50.7-52.2)$ \\
\hline Not drinking alcohol & 1,238 & $7.9(7.4-8.3)$ \\
\hline Drinking less & 2,027 & $13.0(12.4-13.5)$ \\
\hline Same consumption as before & 3,165 & $20.2(19.5-20.8)$ \\
\hline Drinking more & 1,112 & $7.1(6.6-7.5)$ \\
\hline $\begin{array}{l}\text { I had stopped drinking but started } \\
\text { drinking again }\end{array}$ & 47 & $0.3(0.2-0.4)$ \\
\hline \multicolumn{3}{|l|}{ Sleep problems } \\
\hline Did not affect, still sleeping well & 6,554 & $41.9(41.1-42.6)$ \\
\hline $\begin{array}{l}\text { Had sleep problems, but they } \\
\text { improved }\end{array}$ & 138 & $0.9(0.7-1.0)$ \\
\hline $\begin{array}{l}\text { Continued to have the same sleep } \\
\text { problems }\end{array}$ & 1,956 & $12.5(12.3-12.6)$ \\
\hline $\begin{array}{l}\text { Had sleep problems and they got } \\
\text { worse }\end{array}$ & 1,767 & $11.3(10.8-11.7)$ \\
\hline Started having sleep problems & 5,226 & $33.4(32.6-34.1)$ \\
\hline \multicolumn{3}{|l|}{$\begin{array}{l}\text { Use of medication to relax/sleep/ } \\
\text { anxiety/depression }\end{array}$} \\
\hline No & 10,891 & $69.6(68.8-70.3)$ \\
\hline Yes & 4,750 & $30.4(29.6-31.1)$ \\
\hline \multicolumn{3}{|l|}{ Perception of quality of life } \\
\hline Improved & 1,359 & $8.7(8.2-9.1)$ \\
\hline Remained the same & 3,789 & $24.2(23.5-24.8)$ \\
\hline Worsened & 10,493 & $67.1(66.3-67.8)$ \\
\hline \multicolumn{3}{|l|}{ Fear of COVID-19 } \\
\hline Little fear & 4,364 & $27.9(27.1-28.6)$ \\
\hline Moderate fear & 4,446 & $28.4(27.6-29.1)$ \\
\hline Severe fear & 6,831 & $43.7(42.9-44.4)$ \\
\hline \multicolumn{3}{|l|}{$\begin{array}{l}\text { Mental health problems during } \\
\text { the pandemic* }\end{array}$} \\
\hline No & 2,050 & $17.7(17.1-18.3)$ \\
\hline Yes & 9,547 & $82.3(81.7-82.9)$ \\
\hline
\end{tabular}

*Teachers who previously reported a formal diagnosis of depression and/or anxiety during the pandemic were excluded

The sociodemographic profile of the participants was consistent with the profile of Brazilian teachers verified in other studies. ${ }^{13,17}$ This study shows that financial difficulties have affected an important portion of teachers dur- 
ing the pandemic. Almost half of the teachers reported a decrease in family income during the pandemic.

The pandemic has also brought considerable changes in teachers' working conditions. The data show that $99.2 \%$ of the teachers worked virtually during the pandemic. This finding was consistent with a previous study on remote work conducted among Brazilian teachers during the pandemic, which showed that $87 \%$ of the professionals were teaching online classes. ${ }^{13}$ The classroom activities encompass several possibilities, while remote education presents serious limitations, which makes it difficult to meet all the criteria needed according to the national curriculum guidelines. ${ }^{18}$

As for the satisfaction with their work before the COVID-19 pandemic, 4.3\% reported dissatisfaction, and during the pandemic, it increased to $33.7 \%$. Dissatisfaction with work appears to be associated with problems related to physical, mental, and social health, resulting in lower quality of service, increased absenteeism, and evasion from the profession. ${ }^{19}$ Considering the pandemic, dissatisfaction with the teaching work may be related to the urgency of changes in the teacher's work routine. The distance between the teacher and the student can also be a reason for dissatisfaction with the work. Literature shows that teachers develop a feeling of affection and care for students. ${ }^{20,21}$ Casacchia et $\mathrm{al}^{22}$ evaluated the impact and the relationship between distance education and the emotional well-being of teachers during the period of home confinement in Italy. The absence of "face-to-face" eye contact and the difficulty of assessing students' attention was a complaint among the teachers. Therefore, remote education stimulated the weakening of the affective bond between them. In any case, this considerable increase in dissatisfaction with the teaching work deserves attention.

Total adherence to social distance, staying at home and going out only for health care needs, and/or shopping in supermarkets and pharmacies were reported by approximately $80 \%$ of the teachers in the present study. In line with the data shown in this study, another previous study also observed that the adult Brazilian population in general adhered to social distance, with $60 \%$ reporting intense restriction of contact with people and $15 \%$ only leaving home for health care. ${ }^{23}$ In this sense, it is believed that the high prevalence of adherence to social distance by teachers, when compared to the general population, is linked to the positive behavior of the teaching class, pointed out as examples for parents and students, being good "models" to be followed.

More than $87 \%$ of the teachers did not test for COVID-19, and more than $40 \%$ reported flu-like symptoms during the pandemic and $1.2 \%$ tested positive. It must be considered, however, that this study took place in 2020 when the pandemic was still recent and there were not enough tests available for the whole population. A previous study, an online survey with adults, found that $28.1 \%$ had flu-like symptoms after the arrival of the pandemic in Brazil, and $1.3 \%$ of those who reported flu-like symptoms tested positive for COVID-19.24 These results reveal that the teachers did not differ from the adult population towards the issues related to COVID-19. Possibly, this similarity was due to the shutdown of educational institutions and respect for social distance.

A prior study comparing the teachers' perception of quality of life before and during the pandemic shows that their perception has been negatively affected by COVID-19, presenting a significant decrease during the pandemic compared to the pre-pandemic measurement. ${ }^{25}$ In our study, most of the teachers reported a decrease in their quality of life during the pandemic. Among them, 39.8\% started having sleep problems, 8.9\% consumed more alcohol and $48 \%$ did not carry out recreation activities. According to Dankel et al, ${ }^{26}$ lifestyle interferes with the population's quality of life. In this sense, the data from the present study show that there was a worsening in the quality of life of teachers due to the negative changes in their routine acquired during the pandemic.

In general, teachers experienced a worsening in their behaviors and life habits. In this study, there was a high prevalence of physical inactivity, increased body weight, inadequate diet, and increased time dedicated to screens. Other studies have also shown increased health risk behaviors in the daily life of the population during the pandemic, highlighting sedentary behavior and poor health habits. ${ }^{27,28}$ According to Malta et al, ${ }^{12}$ the frequent increase in inappropriate lifestyle during the pandemic is alarming and can cause several health risks, among them, the emergence of chronic non-communicable diseases.

As for mental health problems, more than a quarter of the teachers in our study reported having received a formal diagnosis for anxiety and/or depression during the pandemic. The findings also showed that approximately one-third were consuming medication to relax/sleep/ anxiety/depression, and a third started to have sleep problems after the beginning of the pandemic. A study that analyzed the levels of stress, anxiety, and depression of teachers in Spain found that 32.2\% of the teachers showed a certain degree of depressive symptoms. ${ }^{29}$ Other studies with teachers also show similar results, highlighting the mental health impacts of the pandemic. 22,30 Many negative psychological aspects were seen during the pandemic, such as the fear of infection, frustration, boredom, and inadequate information. ${ }^{31}$ 
A previous study showed that there was a significant prevalence of Brazilians who felt sad or depressed (40.4\%) and anxious or nervous (52.6\%) during the pandemic. In the same study, $43.5 \%$ of the population started having sleep problems during the pandemic, with a higher prevalence in women and people with a formal diagnosis of depression. ${ }^{32}$ These data show that there was a considerable worsening in the quality of sleep of the general population during the pandemic, and should be considered alarming since sleep problems are associated with a worse quality of life, higher occurrence of hypertension, alcohol consumption, physical inactivity, and increased demand for health services. ${ }^{33-37}$

Stachteas and Stachteas ${ }^{38}$ showed that 34\% of teachers experienced a high and a very high degree of fear during the pandemic. Regarding the fear of COVID-19 in our study, it was observed a higher prevalence for severe fear, and among them $86.5 \%$ were women, $57.4 \%$ were aged 41 to 60 years, $25.7 \%$ lost a family member or friend because of COVID-19 and 34.8\% had a medical diagnosis of anxiety and/or depression during the pandemic. According to Shigemura et al, ${ }^{39}$ fear, especially during pandemic times, raises the levels of anxiety and depression in healthy people, with greater severity in psychiatric patients.

Moreover, the study that validated the Fear of COVID-19 Scale for Brazil ${ }^{40}$ showed that $29.4 \%$ of the participants presented severe fear. According to our result, the teachers had a higher prevalence for severe fear of COVID-19 when compared to the Brazilian adult population in general. Thus, it is assumed that these results may make it difficult for teachers to return to classroom activities at school, making it necessary for education managers to be aware of this situation.

The present study has a limitation concerning internet data collection, which brings the possibility of selection bias. However, the literature shows that the research carried out via the internet is promising, as a result of the low costs and the possibility of knowing the health conditions

\section{References}

1. World Health Organization WHO. Emergency Committee. Statement on the second meeting of the International Health Regulations 2005 Emergency Committee regarding the outbreak of novel coronavirus 2019-nCoV. Geneva: WHO, 2020

2. Fundação Oswaldo Cruz Fiocruz. MonitoraCovid-19. Fundação Oswaldo Cruz, Rio de Janeiro 2020. Available from: https://bigdata-covid19.icict.fiocruz.br/

3. Mascha EJ, Schober P, Schefold JC, Stueber F, Luedi MM. Staffing with disease-based epidemiologic indices may reduce shortage of intensive care unit staff during the COVID-19 pandemic. Anesth Analg 2020, 1311:24-40, doi: 10.1213 / ANE.0000000000004849 of the population in real-time. ${ }^{12,23}$ The study also presents a limitation based on the self-report response, leading to the possibility of memory bias. On the other hand, this limitation was minimized by the robustness of the sample, support from DE-MG, and good sample distribution, reaching $93.2 \%$ of the state's municipalities and coverage of $13.3 \%$ of teachers working in the rural area.

The results reveal the dimension of the negative impact of the pandemic on the health and working conditions of teachers, showing the financial difficulties, dissatisfaction with work, the worsening of quality of life and mental health, the increase in body weight, and the intensification of health risk behaviors. Therefore, the COVID-19 pandemic has caused numerous challenges to them.

The findings also show that the course of the pandemic among teachers was not different from the general adult population. However, some issues are specific to teachers, such as increased dissatisfaction with work, remote teaching, being distant from the students and the classroom, and the fear of COVID-19, which was higher among the teachers when compared to the Brazilian population in general.

Furthermore, these results may assist in the development of coherent strategies for the return of classroom activities, health promotion measures, and better working conditions for teachers of public schools, with special emphasis on the most vulnerable teachers. Education is fundamental for the development of the nation and teachers are the protagonists of this process. There will be no quality education without health care and teacher well-being.

\section{Acknowledgements}

We thank the teachers of the State of Minas Gerais for participating in the ProfSMoc Project; the Department of Education of Minas Gerais; the State University of Montes Claros; and the Coordination of Improvement of Higher Education Personnel-Brazil CAPES-Finance Code 001.

4. Aquino E, Silveira IH, Pescarini J, Aquino R, Souza-Filho JÁ, Rocha AS et al. Social distancing measures to control the COVID-19 pandemic: potential impacts and challenges in Brazil. Cien Saude Colet 2020 25:2423-2446, doi: 10.1590/1413-81232020256.1.10502020

5. Daniel SJ. Education and the COVID-19 pandemic. Prospects 2020, 49:91-69, doi: 10.1007/s11125-020-09464-3

6. Vu CT, Hoang AD, Than VQ, Nguyen MT, Dinh VH, Le QAT et al. Dataset of Vietnamese teachers' perspectives and perceived support during the COVID-19 pandemic. Data in brief 2020, 31:105788, doi: 10.1016/j. dib.2020.105788

7. Ministério da Educação. Reorganização do Calendário Escolar e da possibilidade de cômputo de atividades não presenciais para fins de cumprimento da carga horária mínima anual, em razão da Pandemia da 
COVID-19, 2020. Available from: http://portal.mec.gov.br/index.php?option=com_docman\&view=download\&alias=145011-pcp005-20\&category_slug=marco-2020-pdf\&ltemid=30192

8. Monteiro SS. Reinventing scholar education in Brazil at Times of COVID-19. Rev Augustus 2020, 2551:237-254, doi: 10.15202/1981896. 2020v25n51p237

9. Carvalho MRV. Perfil do professor da educação básica. Relatos de Pesquisa. Brasília - DF: 2018. Available from: http://rbep.inep.gov.br/ ojs3/index.php/relatos/article/view/4083/3625

10. Matsuo T, Kobayashi D, Taki F, Sakamoto F, Uehara Y, Mori N et al. Prevalence of Health Care Worker Burnout During the Coronavirus Disease 2019 COVID-19 Pandemic in Japan. JAMA Netw Open 2020, 38:e2017271, doi: 10.1001/jamanetworkopen.2020.17271

11. Luceño-Moreno L, Talavera-Velasco B, García-Albuerne Y, MartínGarcía J. Symptoms of Posttraumatic Stress, Anxiety, Depression, Levels of Resilience and Burnout in Spanish Health Personnel during the COVID-19 Pandemic. Int J Environ Res Public Health 2020, 1715: 5514, doi: 10.3390/ijerph17155514

12. Malta DC, Szwarcwald CL, Barros MBDA, Gomes CS, Machado ÍE, Souza Júnior PRBD et al. The COVID-19 Pandemic and changes in adult Brazilian lifestyles: a cross-sectional study, 2020. Epidemiol Serv Saúde 2020, 294:e2020407, doi: 10.1590/S1679-49742020000400026.

13. Grupo de pesquisa GESTRADO. Trabalho docente em tempos de pandemia. Relatório Técnico. Belo Horizonte; UFMG, 2020. Available from: https://www.uncme.org.br/Gerenciador/kcfinder/upload/files/ cnte_relatorio_da_pesquisa_covid_gestrado_v02.pdf

14. Secretaria de Estado de Educação de Minas Gerais. Relação de estabelecimentos de ensino ativos em Minas Gerais. 2020. Available from: https://www2.educacao.mg.gov.br/mapa-do-site/parceiro/lista-de-escolas

15. Eysenbach G. Improving the quality of Web surveys: the Checklist for Reporting Results of Internet E-Surveys (CHERRIES). J Med Internet Res 2004, 6:e34, doi: 10.2196/jmir.6.3.e34

16. Ahorsu DK, Lin CY, Imani V, Saffari M, Griffiths MD, Pakpour AH. The Fear of COVID-19 Scale: Development and Initial Validation. Int J Ment Health Addict 2020, 1-9, doi: 10.1007/s11469-020-00270-8

17. Bezerra ACV, Silva CEMD, Soares FRG, Silva JAMD. Factors associated with people's behavior in social isolation during the COVID-19 pandemic. Ciênc Saúde Coletiva 2020, 25:2411-2421, doi: 10.1590/141381232020256.1.10792020

18. Carneiro LA, Rodrigues W, França G, Prata DN. Use of technologies in Brazilian public higher education in times of pandemic COVID-19. Res, Soc Develop 2020, 98: e267985485-e267985485, doi: 10.33448/ rsd-v9i8.54851

19. Cardoso CGLDV, Costa NMDSC. Factors connected with professional satisfaction and dissatisfaction among nutrition teachers. Ciênc Saúde Colet 2016, 21:2357-2364, doi: 10.1590/1413-8123201521803862016

20. Fernandes-Silva KM. Lecionar: um ato de amor ou somente o exercício de uma profissão? [dissertação]. Santos SP: Universidade Católica de Santos - Católica de Santos; 2008. Available from: http://biblioteca. unisantos.br:8181/handle/tede/120.

21. Maia H. Being a female teacher: Feminilization and depreciation of teaching. Rev Edu Cultura Contemp 2009, 612. Available at http://periodicos.estacio.br/index.php/reeduc/article/view/7777/47966551

22. Casacchia M, Cifone MG, Giusti L, Fabiani L, Gatto R, Lancia $L$ et al Distance education during COVID 19: an Italian survey on the university teachers' perspectives and their emotional conditions. BMC Med Educ 2021, 21:335, doi:10.1186/s12909-021-02780-y

23. Szwarcwald CL, Souza Júnior PRBD, Malta DC, Barros MBDA, Magalhães MDAFM, Xavier DR et al. Adherence to physical contact restriction measures and the spread of COVID-19 in Brazil. Epidemiol Serv Saúde 2020, 295:e2020432, doi: 10.1590/S1679-49742020000500018
24. Almeida WDS, Szwarcwald $C L$, Malta DC, Barros MBA, Souza Júnior PRB, Azevedo LO et al. Changes in Brazilians' socioeconomic and health conditions during the COVID-19 pandemic. Rev Bras Epidemiol 2020, 23:E200105, doi: 10.1590/1980-549720200105

25. Lizana PA, Vega-Fernadez G, Gomez-Bruton A, Leyton B, Lera L. Impact of the COVID-19 Pandemic on Teacher Quality of Life: A Longitudinal Study from before and during the Health Crisis. Int J Environ Res Public Health 2021, 18:3764, doi:10.3390/ijerph18073764

26. Dankel SJ, Loenneke JP, Loprinzi PD. Physical activity and diet on quality of life and mortality: The importance of meeting one specific or both behaviors. Int J Cardiol 2016, 202:328-30, doi: 10.1016/j. ijcard.2015.09.019

27. Bhutani S, Cooper JA. COVID-19 related home confinement in adults: weight gain risks and opportunities. Obesity 2020, 289: 1576-77, doi: 10.1002/oby.22904

28. Nielsen G. COVID-19: tracking the impact 2020. The Nielsen Company, New York, 2020. Available from: https://www.nielsen.com/us/en/

29. Santamaría MD, Mondragon NI, Santxo NB, Ozamiz-Etxebarria N. Teacher stress, anxiety, and depression at the beginning of the academic year during the COVID-19 pandemic. Glob Ment Health (Camb) 2021,8:e14, doi: 10.1017/gmh.2021.14

30. Akour A, Al-Tammemi AB, Barakat M, Kanj R, Fakhouri HN, Malkawi A, Musleh G. The Impact of the COVID-19 Pandemic and Emergency Distance Teaching on the Psychological Status of University Teachers: A Cross-Sectional Study in Jordan. Am J Trop Med Hyg 2020, 103:23912399, doi: 10.4269/ajtmh.20-0877

31. Brooks SK, Webster RK, Smith LE, Woodland L, Wessely S, Greenberg $\mathrm{N}$ et al. The psychological impact of quarantine and how to reduce it rapid review of the evidence. Lancet 2020, 395:912- 920, doi: 10.1016/ S0140-67362030460-8

32. Barros MBA, Lima MG, Malta DC, Szwarcwald CL, Azevedo RCS, Romero $D$ et al. Report on sadness/depression, nervousness/anxiety and sleep problems in the Brazilian adult population during the COVID-19 pandemic. Epidemol Serv Saúde 2020, 294:e2020427, doi: 10.1590/s1679-49742020000400018

33. Barros MBA, Lima MG, Azevedo RC, Medina LBP, Lopes CS, Menezes PR et al. Depression and health behaviours in Brazilian adults - PNS 2013. Rev Saúde Pública 2017; 51, doi: 10.1590/S1518-8787.2017051000084

34. Del Brutto OH, Mera RM, Zambrano M, Del Brutto VJ, Castillo PR. Association between sleep quality and cardiovascular health: a doorto-door survey in rural Ecuador. Environ Health Prev Med 2014,19:234237, doi:10.1007/s12199-014-0379-5

35. Garcia AN, Salloum IM. Polysomnographic sleep disturbances in nicotine, caffeine, alcohol, cocaine, opioid, and cannabis use: A focused review. Am J Addict 2015, 247: 590-598, doi: 10.1111/ajad.12291

36. Chang JJ, Pien GW, Stamatakis KA, Brownson RC. Association between physical activity and insomnia symptoms in rural communities of southeastern Missouri, Tennessee, and Arkansas. J Rural Health 2013 293:239-247, doi: 10.1111/j.1748-0361.2012.00447.x

37. Godnho MR, Ferreira AP, Santos ASP, Rocha FSA. Factors associated with sleep quality of technical-administrative workers in education of a public university. Rev Med Saude Brasilia 2017, 63:303-320

38. Stachteas $P$, Stachteas C. The psychological impact of the COVID-19 pandemic on secondary school teachers. Psychiatriki 2020, 31:293301, doi: 10.22365/jpsych.2020.314.293

39. Shigemura J, Ursano RJ, Morganstein JC, Kurosawa M, Benedek DM. Public responses to the novel 2019 coronavirus (2019-nCoV) in Japan: Mental health consequences and target populations. Psychiatry Clin Neurosci 2020, 74:281-282, doi:10.1111/pcn.12988

40. Faro A, Santos Silva L, Santos DN, Feitosa ALB. Adaptation and validation of The Fear of COVID-19 Scale. SciELO Preprints 2020, doi: 10.1590/ SciELOPreprints.898 


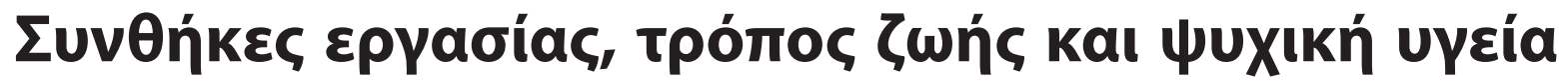

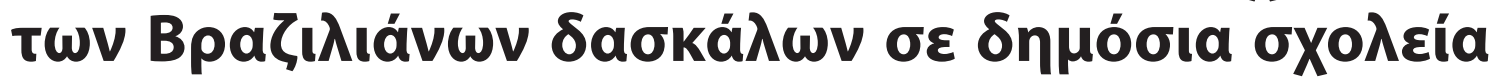

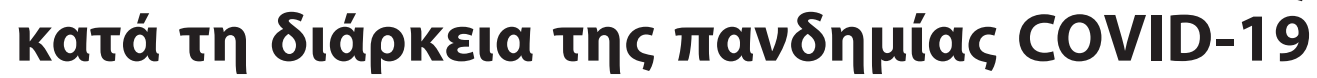

\author{
Nayra Suze Souza e Silva, ${ }^{1}$ Rose Elizabeth Cabral Barbosa, ${ }^{1}$ Luana Lemos Leão, ${ }^{1}$ \\ Geórgia das Graças Pena, ${ }^{2}$ Lucineia de Pinho, ${ }^{3}$ Tatiana Almeida de Magalhães, ${ }^{1}$ \\ Marise Fagundes Silveira, ${ }^{1}$ Luiza Augusta Rosa Rossi-Barbosa, ${ }^{3}$ \\ Rosângela Ramos Veloso Silva, ${ }^{3}$ Desirée Sant'Ana Haikal ${ }^{1}$
}

'Health Sciences Department, State University of Montes Claros - Unimontes, Minas Gerais,

2Health Sciences Department, Federal University of Uberlândia, Uberlândia, Minas Gerais,

${ }^{3}$ Graduate Program in Primary Health Care, State University of Montes Claros - Unimontes, Minas Gerais, Brazil

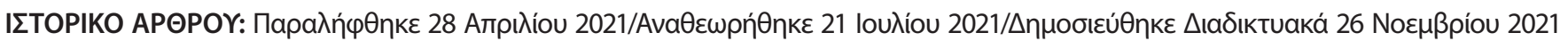

\begin{abstract}
ПЕРІАНЧН

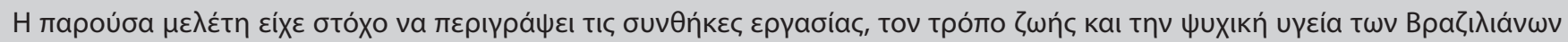

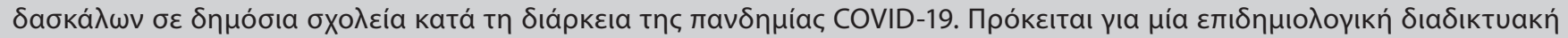

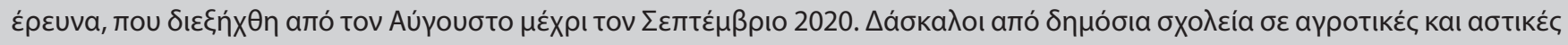

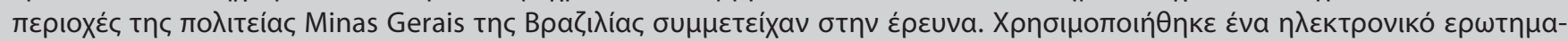

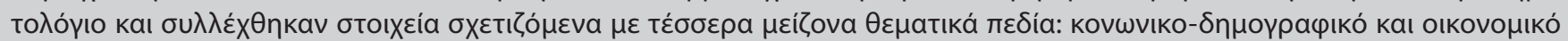

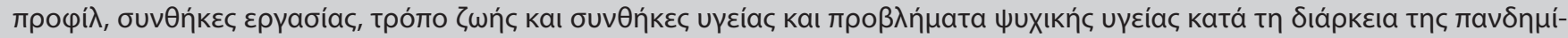

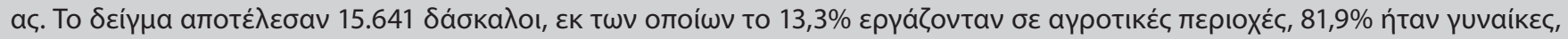

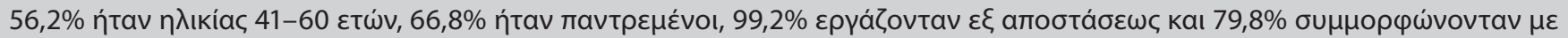

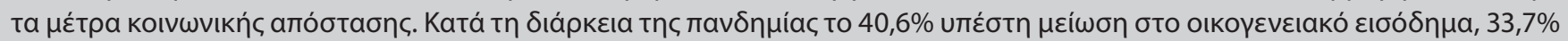

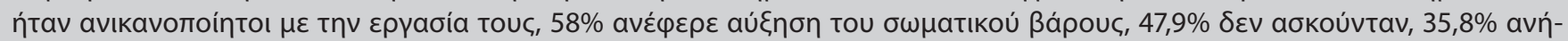

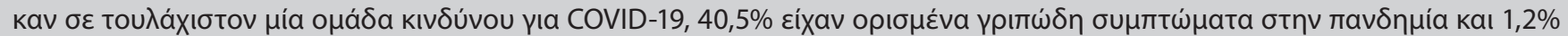

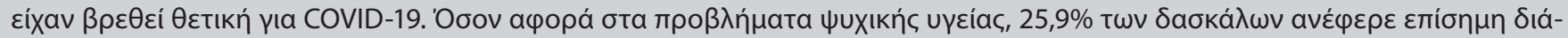

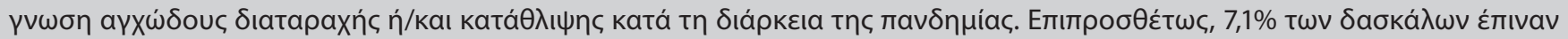

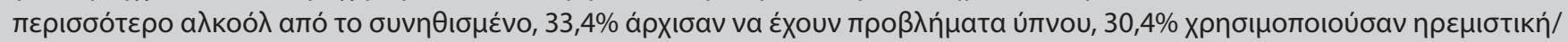

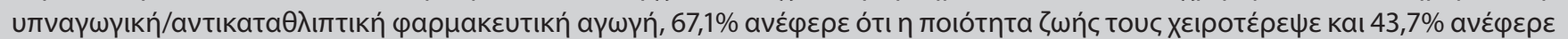

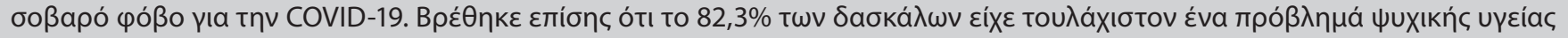

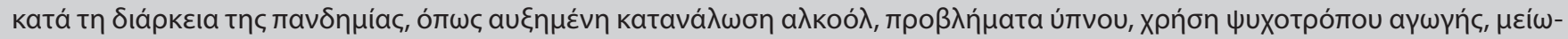

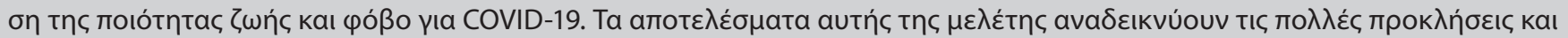

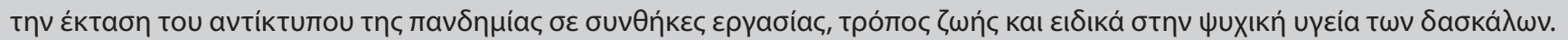

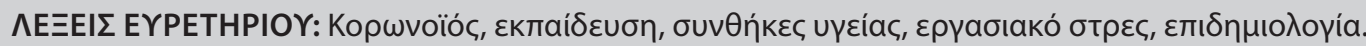

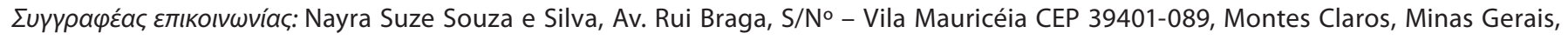
Brazil, $\Delta$ ıú日uvon e-mail: nayrasusy@hotmail.com 